\title{
PERANAN LEMBAGA PENDIDIKAN TENAGA KEPENDIDIKAN DALAM PENGEMBANGAN KUALITAS PENDIDIK DAN TENAGA KEPENDIDIKAN PENDIDIKAN NON FORMAL
}

\begin{abstract}
D. Sudjana*
Abstract

To provide access to education for all Indonesians, the government develops both formal and nonformal education both of which are to produce qualified man power as stated in the Acts of No. 20, 2003. However, to do this non-formal education should have teachers and education personnel fulfilling the requirements of quality and quantity. This article discusses a number of problems in providing teachers and education personnel for non formal education. It invites the universities organizing teachers training to develop programs for the teachers of nonformal education. Due to the big number of the teachers with the variety of specialties needed at present and in the future, this article suggests developing and strengthening the existing teacher training program at the university to become a Faculty of Non Formal Teachers.
\end{abstract}

Key words: competencies, teacher's performances, certification

\section{PENDAHULUAN}

Penjabaran UUD 1945 beserta amandemennya termaktub di dalam Undang-Undang No. 20 Tahun 2005 Tentang Sistem Pendidikan Nasional dan UndangUndang No. 14 Tahun 2005 Tentang Guru dan Dosen, serta tersusunnya Rencana Strategis Depdiknas yang memuat antara lain visi Pendidikan Nasional, dan Peraturan Pemerintah No. 19 Tahun 2005 tentang Standar Nasional Pendidikan.

Visi Depdiknas adalah terwujudnya sistem pendidikan sebagai pranata sosial yang berwibawa dan kuat untuk memberdayakan semua warga negara Indonesia supaya berkembang menjadi manusia yang berkualitas sehingga mampu dan proaktif menjawab tantangan zaman yang selalu berubah. Sejalan dengan visi tersebut, Depdiknas mencanangkan pada tahun
2025 dapat menghasilkan manusia Indonesia seutuhnya yang cerdas dan kompetetif. Kualitas manusia seutuhnya yang cerdas meliputi cerdas spiritual, emosional, sosial, intelektual, dan kinestetis serta mampu menghadapi persaingan global. Kualitas manusia seutuhnya tersebut hanya dapat dihasilkan melalui penyelenggaraan pendidikan yang bermutu, sebagai investasi masa depan bangsa dan negara.

Untuk mencapai sasaran pendidikan yang bermutu, Peraturan Pemerintah No. 19 Tahun 2005 mengharuskan disusunnya standar isi, proses, kompetensi lulusan, pendidik dan tenaga kependidikan, sarana dan prasarana, pengelolaan, pembiayaan, dan penilaian pendidikan baik pada jalur pendidikan formal maupun pendidikan nonformal.

\section{PEMBAHASAN}

\section{Standar Pendidik dan Tenaga Kependidikan}

Undang-Undang No. 14 Tahun 2005 dan

Peraturan Pemerintah No. 19 Tahun 2005 menjelaskan tentang kualifikasi akademik dan kompetensi yang wajib dimiliki oleh pendidik jalur pendidikan formal dan jalur pendidikan nonformal. Lingkup standar pendidik meliputi standar guru, dosen, konselor, pamong belajar, widyaiswara, tutor, instruktur, fasilitator, dan sebutan lain yang sesuai dengan kekhususannya.

Pendidik memiliki kualifikasi akademik dan kompetensi sebagai agen pembelajaran, sehat jasmani dan rohani, serta memiliki kemampuan mewujudkan tujuan pendidikan nasional. Kualifikasi akademik adalah tingkat pendidikan minimal yang harus dipenuhi oleh pendidik, dibuktikan dengan ijazah/sertifikat yang relevan. Dengan kata lain bahwa kualifikasi akademik adalah ijazah yang mencerminkan kemampuan akademik yang diperoleh melalui pendidikan dalam program S1 atau kemampuan vokasional yang diperoleh melalui pendidikan dalam program D4.

Standar kualifikasi pendidik PAUD (TK/RA), SD/ SDLB/Paket A, SMP/MTs/Paket B, SMA/MA/Paket C harus memiliki: (a) kualifikasi pendidikan minimal D4 atau S1; (b) latar belakang pendidikan tinggi program pendidikan khusus atau sarjana yang sesuai dengan mata pelajaran yang diajarkan; (c) sertifikasi profesi pendidik.

* Guru Besar Pendidikan Luar Sekolah UPI Bandung 
Kompetensi adalah seperangkat kemampuan yang dimiliki anggota masyarakat yang mengabdikan diri memangku jabatan profesional untuk menunjang penyelenggaraan pendidikan, yang meliputi kompetensi pedagogik, kompetensi kepribadian, kompetensi profesional, dan kompetensi sosial. Kompetensi pedagogik adalah kemampuan mengelola pembelajaran yang mencakup: pemahaman pada peserta didik (P1), perancangan dan pelaksanaan pembelajaran (P2), evaluasi hasil belajar (P3), dan pengembangan potensi peserta didik (P4). Kompetensi kepribadian adalah kemampuan pribadi pendidik yang mencakup: kepribadian yang mantap (K1), stabil (K2), dewasa (K3), arif (K4), berwibawa (K5), berakhlak mulia (K6), dan dapat menjadi teladan (K7). Kompetensi profesional adalah kemampuan penguasaan materi pembelajaran secara luas dan mendalam yang memungkinkannya dapat membimbing peserta didik memenuhi standar kompetensi yang ditetapkan dalam standar nasional pendidikan ( $\mathrm{Pr} 1)$. Kompetensi sosial adalah kemampuan pendidik sebagai bagian dari masyarakat untuk berkomunikasi dan bergaul secara efektif dengan: peserta didik (S1), sesama pendidik (S2), tenaga kependidikan (S3), orang tua/wali peserta didik (S4), dan masyarakat sekitar (S5). Kriteria fisik dan rohani adalah kelayakan fisik, mental, dan kepribadian yang harus dimiliki seseorang yang bertugas sebagai pendidik yang memungkinkannya dapat melaksanakan tugas profesional dengan sebaik-baiknya. Kualifikasi akademik dan kompetensi sebagai agen pembelajaran dikembangkan oleh BSNP dan ditetapkan dengan Peraturan Menteri.

Asosiasi LPTK Indonesia (2006) menjabarkan kompetensi sebagai agen pembelajaran dalam kompetensi utuh dengan urutan: (1) mengenal secara mendalam peserta didik yang hendak dilayani; (2) menguasai bidang ilmu sumber bahan ajaran baik: (a) menguasai disciplinary content knowledge maupun (b) menguasai pedagogical content knowledge; (3) menyelenggarakan pembelajaran yang mendidik, mencakup: (a) perencangan program pembelajaran berdasarkan serentetan keputusan situasional, (b) implementasi program pembelajaran termasuk midcourse adjustments berdasarkan on-going transactional decisions berhubung dengan reaksi unik dari peserta didik terhadap tindakan pendidik, dan (c) melakukan asesmen proses dan hasil pembelajaran; (4) menggunakan hasil asesmen proses dan hasil pembelajaran untuk perbaikan pengelolaan pembelajaran secara berkelanjutan; dan (5) mengembangkan kemampuan profesional secara berkelanjutan.
Peranan Lembaga Pendidikan Tenaga Kependidikan ...

Tim Pengembang Standar Pendidik dan Tenaga Kependidikan BSNP Depdiknas (2006) menyusun kompetensi pendidik menjadi 30 butir dalam urutan peformansi pendidik sebagai berikut.

1. Mampu mengidentifikasi dan memahami karakteristik peserta didik dari aspek fisik, sosial, moral, kultural, emosional, dan intelektual. (P1)

2. Mampu memfasilitasi pengembangan potensi peserta didik untuk mengaktualisasikan berbagai potensi yang dimilikinya. (P4)

3. Memahami standar kompetensi dan kompetensi dasar mata pelajaran/bidang pengembangan yang diampu. (Pr2)

4. Mampu memilih dan mengembangkan materi pelajaran/bidang pengembangan yang diampu. (Pr2).

5. Menguasai materi, struktur, dan konsep pola pikir keilmuan yang mendukung mata pelajaran/bidang pengembangan yang diampu. ( $\operatorname{Pr} 1)$

6. Menguasai metode untuk melakukan pengembangan ilmu dan telaah kritis yang terkait dengan mata pelajaran/bidang pengembangan yang diampu. $(\operatorname{Pr} 1, \operatorname{Pr} 2)$

7. Kreatif dan inovatif dalam penerapan dan pengembangan bidang ilmu yang terkait dengan mata pelajaran/bidang pengembangan yang diampu. (Pr1, Pr2)

8. Menguasai teori belajar dan prinsip-prinsip pembelajaran yang mendidik. (P2b)

9. Mampu merancang pembelajaran yang mendidik. (P2a)

10. Mampu melaksanakan pembelajaran yang mendidik.(P2b)

11. Mampu merancang penilaian proses dan hasil belajar. (P3)

12. Mampu melaksanakan penilaian proses dan hasil belajar. (P3)

13. Mampu menggunakan hasil penilaian untuk berbagai kepentingan pembelajaran dan pendidikan. (P3)

14. Mampu mengembangkan kurikulum yang terkait dengan mata pelajaran/bidang pengembangan yang diampu. (Pr2)

15. Mampu melakukan tindakan reflektif untuk peningkatan kualitas pembelajaran. (Pr1, Pr2)

16. Mampu berkomunikasi dengan komunitas profesi sendiri dan profesi lain baik secara lisan maupun tulisan. (Pr1, Pr2)

17. Mampu memanfaatkan teknologi informasi dan komunikasi untuk kepentingan pembelajaran, berkomunikasi, dan mengembangkan diri. (Pr2, S2) 
18. Mampu bertindak secara konsisten sesuai dengan norma agama, hukum, sosial, dan kebudayaan nasional Indonesia. (K1,K2,K3,K4,K5)

19. Mampu menampilkan diri sebagai pribadi yang mantap, stabil, dewasa, arif, dan berwibawa. (K1,K2,K3,K4,K5)

20. Mampu menampilkan diri sebagai pribadi yang berakhlak mulia dan sebagai teladan bagi peserta didik dan masyarakat. (K6, K7)

21. Mempunyai rasa bangga menjadi pendidik, dapat bekerja mandiri, mempunyai etos kerja, rasa percaya diri, dan tanggung jawab yang tinggi. (K3, K4)

22. Berperilaku jujur dan disegani. (K6, K7)

23. Mampu mengevaluasi diri dan kinerja secara terus menerus. (K3, K7)

24. Mampu mengembangkan diri secara berkelanjutan dengan belajar dari berbagai sumber ilmu. (Pr1, Pr2, K7)

25. Menjunjung tinggi kode etik profesi pendidik. (K6, K7)

26. Mampu berkomunikasi secara efektif, empatik, dan santun dengan peserta didik. (S1)

27. Mampu berkomunikasi secara efektif, empatik, dan santun dengan sesama pendidik dan tenaga kependidikan. (S2, S3)

28. Mampu berkomunikasi secara efektif, empatik, dan santun dengan orang tua peserta didik dan masyarakat. (S4)

29.Bersikap kooperatif, bertindak objektif, serta tidak diskriminatif karena pertimbangan jenis kelamin, agama, ras, kondisi fisik, latar belakang keluarga, dan status sosial ekonomi. (S1, S2, S3, S4)

30. Mampu beradaptasi di tempat bertugas di seluruh wilayah Republik Indonesia yang memiliki keragaman sosial budaya. (S4)

Sertifikasi adalah tanda pencapaian kompetensi akhir pendidik dinyatakan dalam dokumen ijazah dan atau sertifikat kompetensi. Sertifikat kompetensi diterbitkan oleh satuan pendidikan yang terakreditasi atau oleh lembaga sertifikasi mandiri yang dibentuk oleh organisasi profesi yang diakui Pemerintah sebagai tanda bahwa pendidik yang bersangkutan telah lulus uji kompetensi.

Tenaga kependidikan PNF untuk Paket A/B/C minimal terdiri atas pengelola kelompok belajar, tenaga administrasi, dan tenaga perpustakaan. Tenaga kependidikan untuk lembaga kursus dan pelatihan minimal terdiri atas pengelola, teknisi sumber belajar, pustakawan, dan laboran. Standar untuk setiap jenis pendidik dan tenaga kependidikan PNF dikembangkan oleh BSNP dan ditetapkan dengan Peraturan Menteri.
Pada dasarnya pendidik dan tenaga kependidikan adalah ujung tombak dalam pelaksanaan satuan, jenis, dan program pendidikan nonformal. Pendidik adalah tenaga profesional yang bertugas merencanakan dan melaksanakan proses pembelajaran, menilai hasil pembelajaran, melakukan pembimbingan dan pelatihan, dan pengabdian kepada masyarakat terutama pada perguruan tinggi. Pendidik berkewajiban untuk: (a) menciptakan suasana pendidikan yang bermakna, menyenangkan, kreatif, dan dialogis; (b) mempunyai komitmen secara profesional untuk meningkatkan mutu pendidikan; dan (c) memberi teladan dan menjaga nama baik lembaga, profesi, dan kedudukan sesuai dengan kepercayaan yang diberikan kepadanya. Pendidik pada pendidikan nonformal terdiri atas pamong belajar, tutor, instruktur, Tenaga Lapangan Dikmas (TLD), Nara Sumber Teknis (NST), dan pamong Pendidikan Anak Usia Dini (PAUD). Adapun tenaga kependidikan adalah tenaga yang bertugas melaksanakan administrasi, pengelolaan, pengembangan, pengawasan, dan pelayanan teknis untuk menunjang proses pendidikan pada satuan pendidikan. Tenaga kependidikan tersebut terdiri atas penilik, penyelenggara/pengelola satuan pendidikan, pustakawan, dan tenaga profesional organisasi pendidik dan tenaga kependidikan pendidikan nonformal (PTK-PNF). Kendati banyak yang terlibat dalam pendidikan nonformal tetapi pemegang peran utama (the major actor) adalah pendidik itu sendiri.

\section{Kondisi Pendidik dan Tenaga Kependidikan Pendidikan Nonformal}

Menurut data yang diolah dari Dit PTK-PNF Ditjen PMPTK, jumlah pendidik pendidikan nonformal yang diselenggarakan Depdiknas pada 32 provinsi dalam tahun 2004 terdiri atas: (a) pamong belajar yang dibutuhkan 4.775 orang, yang ada 3.432, kekurangan 1.343 orang; (b) Tenaga Lapangan Dikmas (TLD) yang dibutuhkan 10.184, yang ada 5.043, kekurangan 5.136 orang; (c) fasilitator desa binaan intensif yang dibutuhkan 1.682, yang ada 1.492, kekurangan 80 orang; (d) pamong PAUD yang dibutuhkan 355.235, yang ada 48.207, kekurangan 307.028 orang; (e) tutor program KF dan paket $A$ yang dibutuhkan 7.177, yang ada 4.715, kekurangan 2.462 orang; ( $f$ ) tutor paket $B$ dan $\mathrm{C}$ yang dibutuhkan 6.412 , dan yang ada 6.412 orang. Tenaga kependidikan yang ada adalah penilik dan pengelola PKBM. Penilik yang dibutuhkan 13.800, yang ada 6.861 , kekurangannya 7.149 orang dan Pengelola PKBM berjumlah 9.128 orang. Dengan demikian jumlah tenaga pendidik yang ada 69.301 dan kekurangan nya 315.956 orang, sedangkan tenaga 
kependidikan yang ada 15.989 , kekurangannya 7.149 orang. Jadi, seluruh pendidik dan tenaga kependidikan pendidikan nonformal yang ada berjumlah 85.290 orang dan tenaga yang masih dibutuhkan sebanyak 323.105 orang.

Permasalahan yang dihadapi adalah: (a) jumlah pendidik dan tenaga kependidikan pendidikan nonformal (PTK-PNF) belum memadai; (b) distribusi PTK-PNF tidak merata; (c) kualifikasi dan kompetensi belum memenuhi standar; (d) terbatasnya kemampuan pemerintah dalam memenuhi kebutuhan PTK-PNF; (e) penghargaan, kesejahteraan, dan perlindungan PTK-
PNF belum dilaksanakan secara maksimal; $(\mathrm{g})$ kualitas output UPT belum optimal; (h) belum berkembangnya organisasi profesi PTK-PNF; dan (i) manajemen belum efektif dan efisien. Masalah lain adalah masih ada disparitas dalam ketersediaan pendidik dan tenaga kependidikan pada satuan, jenis dan program pendidikan nonformal. Pendidik yang melakukan tugas tidak sesuai dengan bidang keahlian dan kualifikasi akademik (mismatch) amat banyak terjadi. Dengan demikian PTK-PNF masih jauh dari standar yang ditetapkan dalam Undang-Undang Guru dan Dosen, serta PP No. 19 tentang Standar Nasional Pendidikan.

\section{PENUTUP}

LPTK berperan untuk menghasilkan PTK-PNF yang dapat memenuhi kebutuhan tenaga baru. Dalam hal ini LPTK berfungsi sebagai penyelenggara pendidikan untuk menghasilkan para calon PTK-PNF dalam jumlah dan mutu yang memadai. Namun melihat kondisi PTK-PNF di lapangan yang sebagian besar belum memiliki kualifikasi akademik dan kompetensi sebagai agen pembelajaran serta tenaga kependidikan yang disyaratkan maka LPTK perlu pula melayani lembaga pemakai untuk melakukan pendidikan lanjutan dan atau pelatihan bagi PTK-PNF sehingga secara bertahap mereka dapat memiliki kualifikasi akademik dan kompetensi sesuai dengan peraturan perundangundangan yang berlaku. Dengan demikian, LPTK berperan menyelenggarakan pendidikan prajabatan (prae-service education) untuk menyiapkan PTK-PNF baru yang memenuhi standar nasional pendidikan. Secara kolaboratif LPTK menyelenggarakan pendidikan dalam jabatan untuk menyesuaikan kualifikasi akademik dan kompetensi PTK-PNF yang sedang bertugas di lapangan.

Dalam melaksanakan peran tersebut LPTK perlu memantapkan visi yang berorientasi pada tersedianya PTK-PNF yang cerdas dan kompetitif secara nasional dan internasional sehingga dapat memenuhi kebutuhan masyarakat dan bangsa.

Untuk mewujudkan visi tersebut misi yang harus dilakukan LPTK adalah sebagai berikut:

a. Memperbaharui dan mengembangkan sistem pendidikannya yang berorientasi pada dampak (outcome) bagi tersedianya PTK yang memenuhi kualifikasi akademik dan kompetensi pembelajaran sesuai dengan kebutuhan pengguna lulusan, dengan memperhatikan masukan lingkungan, masukan sarana, masukan mental, masukan lain, dan proses pembelajaran yang mendidik, dialogis, dan partisipatif. b. Mengembangkan program studi di LPTK-PNF dengan menyusun berbagai konsentrasi untuk memenuhi kualifikasi akademik dan kompetensi berdasarkan satuan-satuan PNF. Seharusnya konsentrasi dalam program studi LPTK-PNF terdiri atas: Pendidikan Keluarga, Pendidikan Anak Usia Dini (PAUD), Kelompok Belajar (keaksaraan fungsional, kesetaraan, kelompok belajar usaha), Kursus, Pelatihan, Majelis Ta'lim, PKBM, Satuan pendidikan yang sejenis seperti Penyuluhan, Magang, Bimbingan Belajar, Padepokan, Sanggar, Pesantren, Keterampilan Fungsional, dan kegiatan ekstra kurikuler pada pendidikan formal.

c. Pengembangan kurikulum program studi untuk prajabatan dan dalam jabatan. Sesuai dengan kesepakatan Asosiasi LPTK, kurikulum LPTK PTKPNF untuk prajabatan hendaknya disusun secara utuh yang berbobot antara 160-166 sks, terdiri atas MKU-14 sks, MKP-30 sks, dan MKK (termasuk kurikulum konsentrasi) - 100-106 sks. Di dalamnya tercakup kurikulum program sertifikasi (40) sks, terdiri atas 4 kompetensi dalam enam rumpun yaitu: (1) kompetensi pedagogik (dengan rumpun IImu Pendidikan, Penguasaan Bidang Studi, Pembelajaran Bidang Studi, Praktek Pendidikan), (2) kompetensi profesional (kemampuan profesional PTK-PNF), (3) kompetensi kepribadian (kepribadian PTK-PNF), dan (4) kompetensi sosial (kemampuan berkomunikasi). Rancangan struktur program sertifikasi PTK-PNF (40 sks) mencakup: Landasan Pendidikan (2 sks), Belajar dan Pembelajaran (4 sks), Perkembangan Peserta Didik (3 sks), Perencanaan Pembelajaran (4 sks), Evaluasi Pembelajaran (4 sks), Media Pembelajaran (3 sks), Bimbingan dan Konseling (2 sks), Komunikasi Pendidikan (2 sks), Profesi Kependidikan (2 sks), 
Penelitian Tindakan Kelas ( 3 sks), Telaah Kurikulum (3 sks), dan PPL (8 sks). Pendidikan profesi diselenggarakan setelah selesai jenjang $S 1$. Oleh karena itu LPTK perlu menyelenggarakan pendidikan profesi bagi PTK-PNF pada jenjang pascasarjana.

d. Penyelenggaraan program pendidikan dalam jabatan (in-service education/training) yang perlu dilakukan secara kolaboratif antara LPTK dengan Lembaga Penyelenggara Program PNF di lingkungan Depdiknas dan atau lembaga lainnya. Program pendidikan dalam jabatan meliputi pendidikan khusus untuk peningkatan kualifikasi akademik (meng-S1-kan) PTK-PNF yang bertugas di lapangan, pembelajaran kompetensi sebagai agen pembelajaran, uji dan kompetensi yang kelulusannya menjadi syarat memperoleh sertifikasi. Pendidikan prajabatan dilakukan baik secara reguler maupun melalui pembelajaran jarah jauh (distance learning) dengan menggunakan sistem ganda (dual-mode systems). e. Melihat luasnya satuan, jenis, dan program-program PNF, besarnya usia penduduk yang tidak terlayani pendidikan formal, dan meningkatnya kebutuhan pendidik dan tenaga kependidikan PNF maka sudah saatnya semua LPTK bersepakat untuk meningkatkan status jurusan atau program studi PLS/PNF menjadi Fakultas Kependidikan PNF. Fakultas ini yang akan mengembangkan program-program studi berdasarkan satuan-satuan PNF sebagaimana ditetapkan dalam Undang-Undang No. 20 Tahun 2003 pasal 26, 27,28,29,30, dan 31 dalam jalur pendidikan nonformal dan informal. Dengan demikian LPTK tidak hanya berkiprah dalam penyediaan dan peningkatan pendidik dan tenaga kependidikan pada jalur (subsistem) pendidikan formal, tetapi juga dalam penyediaan dan pengembangan pendidik dan tenaga kependidikan pada jalur (subsistem) pendidikan formal dan pendidikan informal.

\section{DAFTAR PUSTAKA}

Asosiasi LPTK Indonesia. (2006). Penyelenggaraan program sertifikasi guru. Makalah disampaikan pada Rapat Tim Pengembang Standar Kompetensi Pendidik dan Tenaga Kependidikan BSNP.

Departemen Pendidikan Nasional. (2005). Rencana strategis 2005-2009: Peningkatan kapasitas dan modernisasi. Jakarta: Depdiknas.

Direktorat PTK-PNF Ditjen PMPTK (2006). Kebijakan dan Program Direktorat Pendidikan dan Tenaga Kependidikan Nonformal. Presentasi pada Rapat Tim Pengembang Standar Pendidik dan Tenaga Kependidikan BSNP Jakarta.

Sudjana, D. (2004). Pendidikan nonformal: Wawasan, sejarah perkembangan, falsafah dan teori pendukung, serta azas. Bandung: Falah Production.
Sudjana, D. (2005). Manajemen program dan ketenagaan pendidikan nonformal. Makalah disampaikan pada Workshop Profesionalisme Guru Berprestasi Tingkat Nasional di Yogyakarta dan Denpasar. Jakarta: Ditjen PMPTK.

Sudjana, D. (2006). Prospek pendidikan luar sekolah: Berdasarkan undang-undang nomor 14 tahun 2005 tentang guru dan dosen serta peraturan pemerintah nomor 19 tahun 2005 tentang standar nasional pendidikan. FKIP-UIKA Bogor.

Tim Pengembang Standar Pendidik dan Tenaga Kependidikan BSNP. (2006). Naskah akademik standar pendidik. Jakarta: BSNP Depdiknas (tidak dipublikasikan).

Tim Pengembang Standar Pendidik dan Tenaga Kependidikan BSNP. (2006). Standar kompetensi inti (Core-competency) Guru. Jakarta: BSNP Depdiknas (tidak dipublikasikan). 